\title{
Antimicrobial activity of fermented Maillard reaction products, novel milk-derived material, made by whey protein and Lactobacillus rhamnosus and Lactobacillus gasseri on Clostridium perfringens
}

\author{
Yujin Kim${ }^{1}$, Sejeong Kim², Soomin Lee ${ }^{2}$, Jimyeong $\mathrm{Ha}^{2}$, Jeeyeon Lee ${ }^{3}$, Yukyung $\mathrm{Choi}^{2}$, Hyemin $\mathrm{Oh}^{1}$, \\ Yewon Lee ${ }^{1}$, Nam-su $\mathrm{Oh}^{4}$, Yohan Yoon ${ }^{1, *}$, and Heeyoung Lee ${ }^{5, \star}$
}

\author{
* Corresponding Authors: \\ Yohan Yoon \\ Tel: +82-2-2077-7585, Fax: +82-2-710-9479, \\ E-mail:yyoon@sookmyung.ac.kr \\ Heeyoung Lee \\ Tel: +82-63-219-9454, Fax: +82-63-219-9333, \\ E-mail: hylee06@kfri.re.kr \\ 1 Department of Food and Nutrition, \\ Sookmyung Women's University, Seoul \\ 04310, Korea \\ ${ }^{2}$ Risk Analysis Research Center, Sookmyung \\ Women's University, Seoul 04310, Korea \\ ${ }^{3}$ Department of Food and Nutrition, Dong-eui \\ University, Busan 47340, Korea \\ ${ }^{4}$ Department of Food and Biotechnology, \\ Korea University, Sejong 30019, Korea \\ ${ }^{5}$ Food Standard Research Center, Korea Food \\ Research Institute, Wanju 55365, Korea \\ ORCID \\ Yujin Kim \\ https://orcid.org/0000-0002-0903-9871 \\ Sejeong Kim \\ https://orcid.org/0000-0001-9741-8056 \\ Soomin Lee \\ https://orcid.org/0000-0003-1811-7365 \\ Jimyeong $\mathrm{Ha}$ \\ https://orcid.org/0000-0001-7973-7926 \\ Jeeyeon Lee \\ https://orcid.org/0000-0002-5885-6835 \\ Yukyung Choi \\ https://orcid.org/0000-0002-7994-9862 \\ Hyemin Oh \\ https://orcid.org/0000-0002-8073-7242 \\ Yewon Lee \\ https://orcid.org/0000-0001-8715-1140 \\ Nam-su Oh \\ https://orcid.org/0000-0002-0712-7843 \\ Yohan Yoon \\ https://orcid.org/0000-0002-4561-6218 \\ Heeyoung Lee
}

https://orcid.org/0000-0001-6115-9179

Submitted May 1, 2020; Revised Jun 21, 2020; Accepted Feb 2, 2021
Objective: The objective of this study was to evaluate the antimicrobial effects of fermented Maillard reaction products made by milk proteins (FMRPs) on Clostridium perfringens ( $C$. perfringens), and to elucidate antimicrobial modes of FMRPs on the bacteria, using physiological and morphological analyses.

Methods: Antimicrobial effects of FMRPs (whey protein plus galactose fermented by Lactobacillus rhamnosus [L. rhamnosus] 4B15 [Gal-4B15] or Lactobacillus gasseri 4M13 [Gal-4M13], and whey protein plus glucose fermented by L. rhamnosus 4B15 [Glc-4B15] or L. gasseri 4M13 [Glc-4M13]) on C. perfringens were tested by examining growth responses of the pathogen. Iron chelation activity analysis, propidium iodide uptake assay, and morphological analysis with field emission scanning electron microscope (FE-SEM) were conducted to elucidate the modes of antimicrobial activities of FMRPs.

Results: When C. perfringens were exposed to the FMRPs, C. perfringens cell counts were decreased $(\mathrm{p}<0.05)$ by the all tested FMRPs; iron chelation activities by FMRPs, except for Glc-4M13. Propidium iodide uptake assay indicate that bacterial cellular damage increased in all FMRPs-treated $C$. perfringens, and it was observed by FE-SEM.

Conclusion: These results indicate that the FMRPs can destroy C. perfringens by iron chelation and cell membrane damage. Thus, it could be used in dairy products, and controlling intestinal C. perfringens.

Keywords: Antimicrobial Effects; Clostridium perfringens; Fermented Maillard Reaction Products

\section{INTRODUCTION}

Clostridium perfringens, gram-positive and spore-forming anaerobe, is the third common cause of foodborne illness in United States [1]. Also, this bacterium is responsible for the symptoms, such as abdominal cramps and severe diarrhea, caused by ingestion of food which is contaminated in large number of $C$. perfringens, especially proteinaceous foods, meat, and poultry [2]. Besides, $C$. perfringens generally inhabits in a human gut, and its prevalence in the gut increases, as humans get old [3]. A significant proportion of this bacterium in gut microbiota may be associated with autism in children and neurological disorders, such as neuromyelitis optica [4-6]. The virulence of $C$. perfringens attributes to its toxins, especially $C$. perfringens enterotoxin (CPE) produced during its sporulation in intestines [7]. Due to its ability to bind to claudin receptors, which are junction proteins in intestines, it is known that $\mathrm{CPE}$ creates pore on the cell membrane and results in cell 
death, causing diarrhea and abdominal pain [7]. Thus, this bacterium needs to be controlled. However, there are no edible materials which are applicable to human for destroying $C$. perfringens specifically inhabits in intestines.

In previous studies, glycated milk proteins, such as whey protein glycated with galactose and glucose, were studied for anti-inflammatory activities and their protective effects against oxidative stress [8,9]. Furthermore, fermented Maillard reaction products (FMRPs), which were produced from glycated milk proteins, have recently been introduced for their physiological functions, such as antioxidant, antihypertensive, antithrombotic, and hepatoprotective properties [10,11]. It was reported that antimicrobial activities of Maillard reaction products vary according to the kinds of amino acids [12]. Moreover, Maillard reaction products, which were derived from the foods, such as coffee, beer, and wine, showed different antimicrobial activities $[13,14]$. Meanwhile, the antimicrobial activity of FMRPs has never been investigated yet to date. Moreover, the effect of Maillard reaction products against the bacteria inhabiting gastrointestinal tract was not elucidated. In order to reduce incidence of diseases due to the pathogenicity of intestinal microbes, and risks such as antibiotics and stress tolerance, it is necessary to study FMRPs possessing physiological and antimicrobial activities. Therefore, the objective of this study was to evaluate the antimicrobial activity of FMRPs against $C$. perfringens and to elucidate the mode of FMRPs for antimicrobial activity.

\section{MATERIALS AND METHODS}

Preparation of fermented Maillard reaction products FMRPs were prepared with whey protein (Davisco Foods International Inc., Le Sueur, MN, USA), sugars (galactose or glucose), and lactic acid bacteria (Lactobacillus rhamnosus $4 \mathrm{~B} 15$ or Lactobacillus gasseri 4M13) (Table 1). For Maillard reaction, $50 \mathrm{mg} / \mathrm{g}$ of whey protein isolate and $25 \mathrm{mg} / \mathrm{g}$ of sugar (galactose or glucose) were mixed in deionized water, followed by shaking at $60 \mathrm{rpm}$ in a pilot-scale instrument controlled by a pilot-scale pasteurization unit (Powerpoint International, Tokyo, Japan) at $65^{\circ} \mathrm{C}$ for $24 \mathrm{~h}$. These Maillard reacted galactose and glucose were then fermented by $L$. rhamnosus $4 \mathrm{~B} 15$ or L. gasseri $4 \mathrm{M} 13$ at 6 Log colony-forming unit $(\mathrm{CFU}) / \mathrm{mL}$ at $37^{\circ} \mathrm{C}$ for $48 \mathrm{~h}$ to prepare FMRPs (Gal-4B15, Gal-4M13, Glu-

Table 1. Fermented Maillard reaction products examined for antimicrobial activity on Clostridium perfringens, produced by whey protein and sugars fermented by lactic acid bacteria

\begin{tabular}{llll}
\hline Milk proteins & Sugars & Lactic acid bacteria & Treatment code \\
\hline Whey protein & Galactose & L. rhamnosus 4B15 & Gal-4B15 \\
& & L. gasseri 4M13 & Gal-4M13 \\
& Glucose & L. rhamnosus 4B15 & Glc-4B15 \\
& & L. gasseri 4M13 & Glc-4M13 \\
\hline
\end{tabular}

$4 \mathrm{~B} 15$, and Glu-4M13). The cultures were then centrifuged at 2,000 $\times g$ for 30 min (Hitachi CR-21G rotor R20A, Hitachi Ltd., Tokyo, Japan). Subsequently, the supernatants were transferred into aluminum containers, followed by freeze-drying using a lyophilizer (OPERON FDUT-8608, Gimpo, Gyeonggi, Korea) for $72 \mathrm{~h}$. The freeze-dried FMRPs were powdered and stored at $4^{\circ} \mathrm{C}$ until further use.

\section{Bacterial preparation}

To evaluate antimicrobial effects of FMRPs on $C$. perfringens, $1 \mathrm{~mL}$ of $C$. perfringens strains NCCP15911, NCCP15912, NCCP10846, NCCP10858, NCCP10976, and NCCP10347 were inoculated in $10 \mathrm{~mL}$ cooked meat medium (Oxoid, Basingstoke, Hampshire, UK), and the cultures were placed in airtight containers with Anaerogen (Oxoid, UK), followed by incubation at $37^{\circ} \mathrm{C}$ for $24 \mathrm{~h}$. Then, $0.1 \mathrm{~mL}$ aliquots of the cultures were inoculated into $9 \mathrm{~mL}$ fresh brain-heart infusion (BHI; BD Difco, Sparks, MD, USA), followed by anaerobic incubation at $37^{\circ} \mathrm{C}$ for $24 \mathrm{~h}$. The subcultures were mixed, and then centrifuged at $1,912 \times g$ and $4^{\circ} \mathrm{C}$ for $15 \mathrm{~min}$. The cell pellets were washed twice with phosphate buffered saline (PBS, pH 7.4; $0.2 \mathrm{~g}$ of $\mathrm{KH}_{2} \mathrm{PO}_{4}, 1.5 \mathrm{~g}$ of $\mathrm{Na}_{2} \mathrm{HPO}_{4}, 8.0 \mathrm{~g}$ of $\mathrm{NaCl}$, and $0.2 \mathrm{~g}$ of $\mathrm{KCl}$ in $1 \mathrm{~L}$ of distilled water). The cell suspensions of $C$. perfringens were then diluted to $\mathrm{OD}_{600}=0.01$ with PBS to obtain 5 to $6 \mathrm{Log} \mathrm{CFU} / \mathrm{mL}$ of inoculum.

\section{Antimicrobial effect of fermented Maillard reaction products}

To evaluate the antimicrobial effects of FMRPs on C. perfringens, a hundred microliters of $C$. perfringens inoculum and $900 \mu \mathrm{L}$ of FMRPs $(100 \mathrm{mg} / \mathrm{mL}$; Gal-4B15, Gal-4M13, Glc$4 \mathrm{~B} 15$, and Glc-4M13) were mixed in a well of a 24 -well plate (SPL Life Sciences, Gyeonggi, Korea), and the plate was placed in an airtight container, containing Anaerogen (Oxoid, UK), followed by anaerobic incubation at $37^{\circ} \mathrm{C}$ for $24 \mathrm{~h}$. The samples were then serially diluted with buffered peptone water (BPW; BD Difco, USA), and $100 \mu \mathrm{L}$ of the diluents were spread-plated on tryptose sulfite cycloserine agar (TSC; Oxoid, UK) to enumerate $C$. perfringens cells.

\section{Iron chelation activity}

To evaluate the iron chelation activity by FMRPs, $100 \mu \mathrm{L}$ of FMRPs $(20 \mathrm{mg} / \mathrm{mL}), 600 \mu \mathrm{L}$ of distilled water, and $100 \mu \mathrm{L}$ of $0.2 \mathrm{mM}$ iron (II) chloride tetrahydrate $\left(\mathrm{FeCl}_{2} \cdot 4 \mathrm{H}_{2} \mathrm{O}\right.$, SAMCHUN chemical Co. Ltd., Seoul, Korea) were mixed, and the mixture reacted for $30 \mathrm{sec}$ at room temperature. Subsequently, $200 \mu \mathrm{L}$ of $0.1 \mathrm{mM}$ Ferrozine (3-(2-Pyridyl)5,6-diphenyl-1,2,4-triazine-p,p'-disulfonic acid monosodium salt hydrate; Sigma Aldrich, St. Louis, MO, USA) were suspended in the mixture, and the samples reacted for $10 \mathrm{~min}$ at room temperature. Thereafter, turbidity of the samples was measured at $562 \mathrm{~nm}$ with a UV-spectrophotometer 
(OPTIZEN 2120UV, Mecasys Co., Ltd., Daejeon, Korea), and iron chelation activity was calculated as follows;

$$
\begin{aligned}
& \text { Iron chelation activity }(\%) \\
& \quad=\left(1-\frac{\text { sample solution absorbance }}{\text { blank solution absorbance }}\right) \times 100
\end{aligned}
$$

Absorbance of blank solution was measured with distilled water instead of with samples [15].

\section{Propidium iodide uptake assay}

To observe the effects of FMRPs on bacterial cell permeability in short time, propidium iodide (PI) uptake assay for FMRPs-exposed C. perfringens was conducted according to the method described by Kim et al [16]. C. perfringens were cultured in cooked meat medium at $37^{\circ} \mathrm{C}$ for $24 \mathrm{~h}$. The bacterial cultures were centrifuged at $10,000 \times g$ for 1 min at room temperature, and supernatants were discarded. One-milliliter portion of each FMRP sample $(200 \mathrm{mg} / \mathrm{mL})$ was transferred to the cell pellets and mixed, followed by incubation at $37^{\circ} \mathrm{C}$ for $60 \mathrm{~min}$. Subsequently, $50 \mu \mathrm{L}$ of $C$. perfringens incubated with FMRP were diluted with $950 \mu \mathrm{L}$ of PBS in a FACS tube (BD Bioscience, San Jose, CA, USA), and $10 \mu \mathrm{L}$ of PI solution $(1 \mathrm{mg} / \mathrm{mL}$ ) (Sigma Aldrich, USA) was then added to the diluted cultures. The mixtures were analyzed with FACSCanto II (BD Bioscience, USA), and PI activities for $C$. perfringens exposed to FMRPs were calculated, using CellQuest Pro software (BD Bioscience, USA). The percentages of FMRPs-treated bacteria figured in each histogram are relatively calculated to PBS-treated bacteria at a same designated point.

\section{Morphological observation}

To elucidate the antimicrobial activity of FMRPs against $C$. perfringens, morphological observations were conducted, using field emission scanning electron microscope (FESEM; JEOL JSM-7600F, JEOL USA Inc., Peabody, MA, USA), according to the method described by Kim et al [16]. $C$. perfringens were cultured in $500 \mu \mathrm{L}$ BHI containing the glass slides anaerobically at $37^{\circ} \mathrm{C}$ for $24 \mathrm{~h}$ with Anaerogen (Oxoid, UK). After incubation, the glass slides were removed from the cultures, and aseptically transferred to sterile 24well flat-bottomed polystyrene plates (SPL, Korea). Thirty milliliters of 1.8\% glutaraldehyde (Sigma-Aldrich Co., St. Louis, MO, USA) were carefully placed over the glass slides, and left for $30 \mathrm{~min}$ at room temperature for the reaction, followed by washing glass slides three times with $1 \mathrm{~mL}$ distilled water for $5 \mathrm{~min}$. Subsequently, the glass slides were treated with $2 \%$ osmium tetroxide solution (Sigma Aldrich, USA) for $20 \mathrm{~min}$ at room temperature for a second fixation, followed by washing them three times with $1 \mathrm{~mL}$ distilled water for $5 \mathrm{~min}$. The fixed bacterial cells on the glass slides were gradually dehydrated with $1 \mathrm{~mL}$ of $25 \%, 50 \%, 75 \%$, $90 \%$, and $100 \%$ ethyl alcohol for 5 min. Afterwards, the glass slides were thoroughly dried with $15 \mu \mathrm{L}$ hexamethyldisilazane (Sigma-Aldrich, USA). The samples were eventually coated with a sputter coater (Cressington 108auto SEM sputter coater, Cressington Scientific Instruments Ltd., Watford, UK), and the bacterial cells were observed, using field emission scanning electron microscopy.

\section{Statistical analysis}

The bacterial cell counts (Log CFU/mL) and iron chelation activity were analyzed by SAS (version 9.2; SAS Institute Inc., Cary, NC, USA), using general linear model procedure. Significant differences of LS-means were analyzed with a pairwise t-test at $\alpha=0.05$.

\section{RESULTS AND DISCUSSION}

\section{Antimicrobial activities of fermented Maillard reaction products}

C. perfringens cell counts in the FMRPs significantly decreased $(\mathrm{p}<0.05)$ at $37^{\circ} \mathrm{C}$ for 12 and $24 \mathrm{~h}$ (Figure 1), regardless of FMRPs used. Especially Gal-4B15 reduced C. perfringens cell counts below detection limit $(10 \mathrm{CFU} / \mathrm{mL})$ even after 12 $\mathrm{h}$ of incubation (Figure 1). This result indicates that FMRPs had significant antimicrobial effects against $C$. perfringens. The functional effects of FMRPs, such as antihypertension and prevention of cardiovascular disease, were found in other studies $[10,11]$. Taken together with the antimicrobial functions of FMRPs against $C$. perfringens, FMRPs may reduce intestinal $C$. perfringens and may be potential materials as health-promoting supplements. Although some fermented dairy products which show antimicrobial activity against $C$. perfringens, such as Kefir and probiotic yogurt, already exist, FMRPs are distinctive due to its antihypertensive and cardiovascular disease-preventive effects [17].

\section{Iron chelation activity}

Theoretically, high iron chelation activity indicates that iron as an essential nutrient for microorganisms in the environment is unavailable to bacteria, which in turn suppresses bacterial growth and decreases bacterial cell counts $[18,19]$. Gal-4M13 (23.87\%) significantly showed high iron chelation activity compared to Glc-4M13 $(0.50 \%)(\mathrm{p}<0.05)$ (Table 2$)$. This suggests that Gal-4M13 may have better iron chelation activities and thus, they may play an important role in inhibiting the growth by limiting uptake of iron in bacterial growth environments. However, only iron chelation activity is not affecting the antimicrobial effects of Gal-4M13 in this study, because Glc-4B15 and Glc-4M13 showed similar antimicrobial effects on $C$. perfringens, although they showed difference in iron chelation activity. 


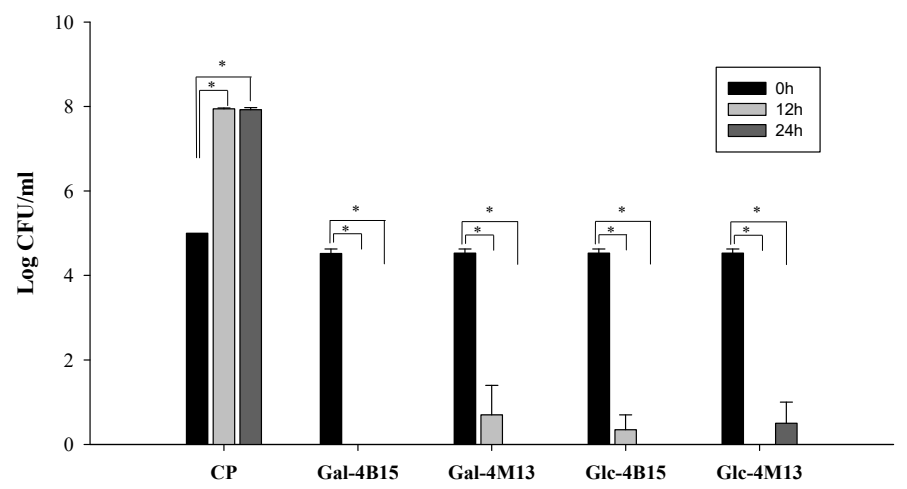

Figure 1. Clostridium perfringens cell counts in fermented Maillard reaction products (Gal-4B15, Gal-4M13, Glc-4B15, and Glc-4M13) according to time for $24 \mathrm{~h}$ at $37^{\circ} \mathrm{C}$. CP, Clostridium perfringens; Gal-4B15, Galactose + L. rhamnosus 4B15; Gal-4M13, Galactose + L. gasseri 4M14; Glc-4B15, Glucose + L. rhamnosus 4B15; Glc-4M13, Glucose + L. gasseri 4M13. * $p<0.05$.

Table 2. Iron chelation activity (\%, mean \pm standard deviation) of fermented Maillard reaction products

\begin{tabular}{lc}
\hline Treatment & $\begin{array}{c}\text { Iron chelation activity } \\
(\%, \text { mean } \pm \text { standard deviation) }\end{array}$ \\
\hline Gal-4B15 & $5.36 \pm 3.16^{\mathrm{AB}}$ \\
Gal-4M13 & $23.87 \pm 1.16^{\mathrm{A}}$ \\
Glc-4B15 & $14.76 \pm 12.82^{\mathrm{AB}}$ \\
Glc-4M13 & $0.50 \pm 7.34^{\mathrm{B}}$ \\
\hline
\end{tabular}

$\overline{A-B}$ Different letters indicate significant differences between means at $p<0.05$.

\section{A. Gal-4B15}
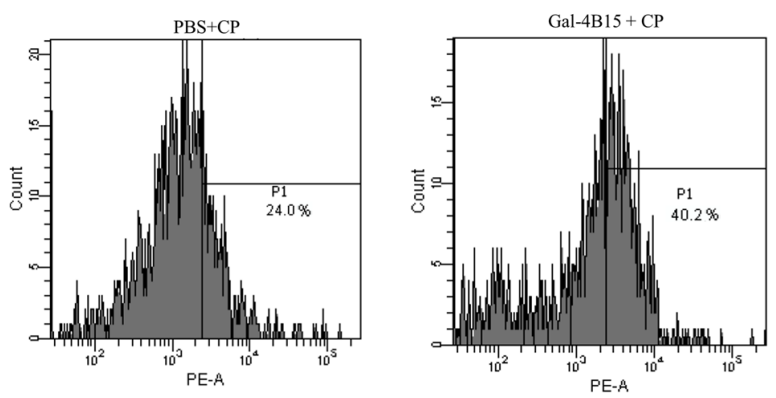

\section{Glc-4B15}
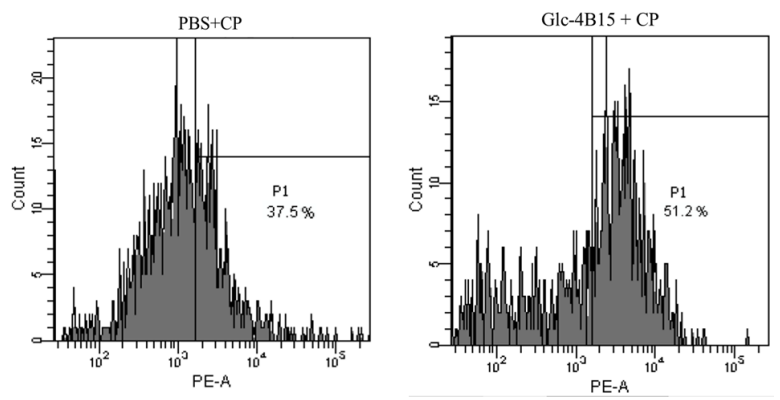

\section{Propidium iodide uptake assay}

In PI uptake assay, movement of peaks in a histogram, which represents the number of events detected at particular intensity, to the right indicates that the cell membrane is damaged. In this study, the movement of the peaks to right, and the change in the shape of the peaks and the number of the events were observed after the FMRPs treatment. Movement of fractions towards right $\mathrm{X}$-axis indicates damages of bacterial cells via detection of wavelength of PI which binds to DNA leaked

\section{B. Gal-4M13}
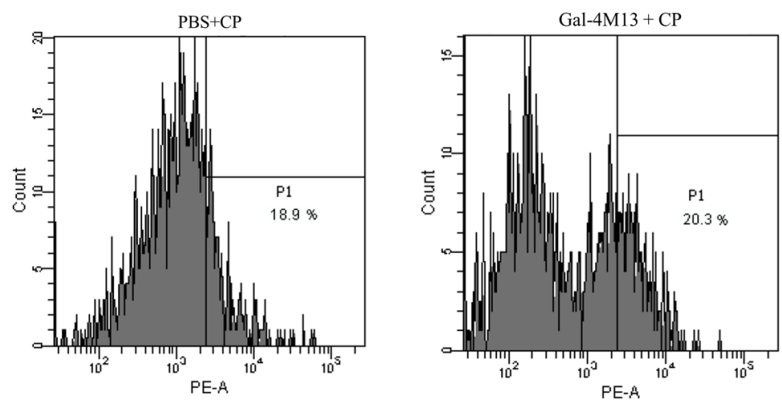

\section{Glc-4M13}
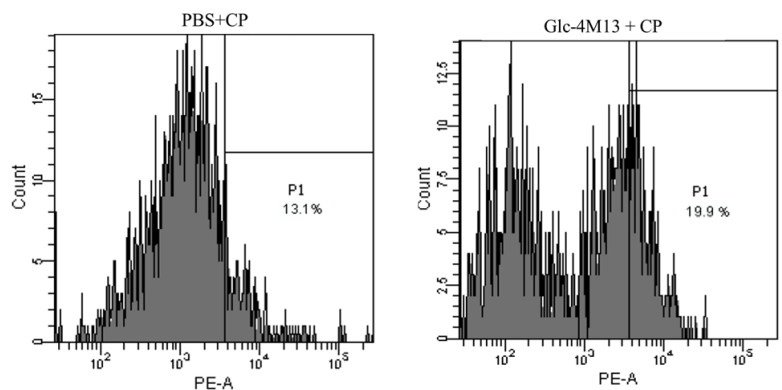

Figure 2. Fluorescent-activated cell sorting histograms of Clostridium perfringens exposed to fermented Maillard reaction products. Prior to measure propidium iodide in each treatment, the histograms were adjusted with PBS-treated C. perfringens (PBS-CP). PI, propidium iodide; PBS, phosphate-buffered saline; CP, C. perfringens; Gal-4B15, Galactose + L. rhamnosus 4B15; Gal-4M13, Galactose + L. gasseri 4M14; Glc-4B15, Glucose + L. rhamnosus 4B15; Glc-4M13, Glucose + L. gasseri 4M13. 
from damaged bacterial cells [20]. The events of treated $C$. perfringens increased from $24.0 \%$ to $40.2 \%$ by Gal-4B15 and from $18.9 \%$ to $20.3 \%$ by Gal-4M13. Glc-4B15 and Glc- $4 \mathrm{M} 13$ treatments also increased the portions of C. perfringens from $37.5 \%$ to $51.2 \%$ and from $13.1 \%$ to $19.9 \%$, respectively (Figure 2). This result indicates that FMRPs caused cell mem-

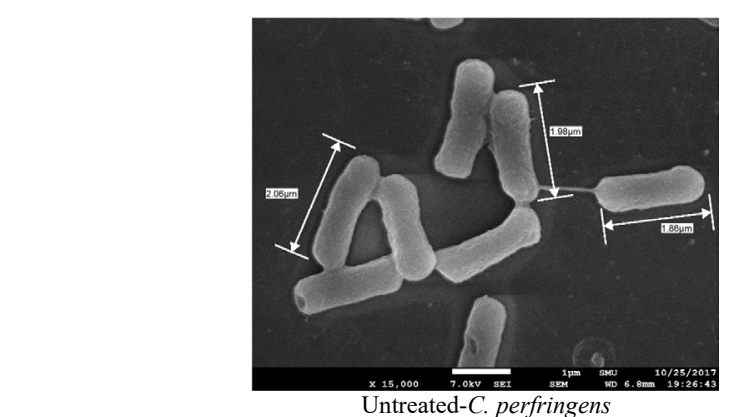

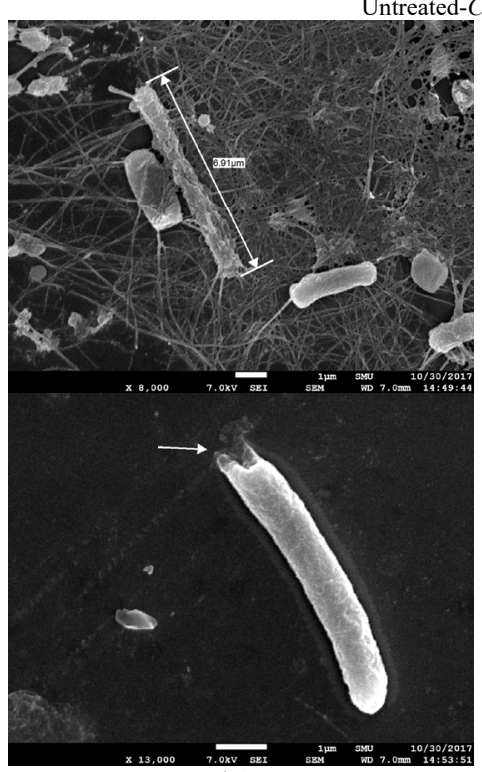

Gal-4B15
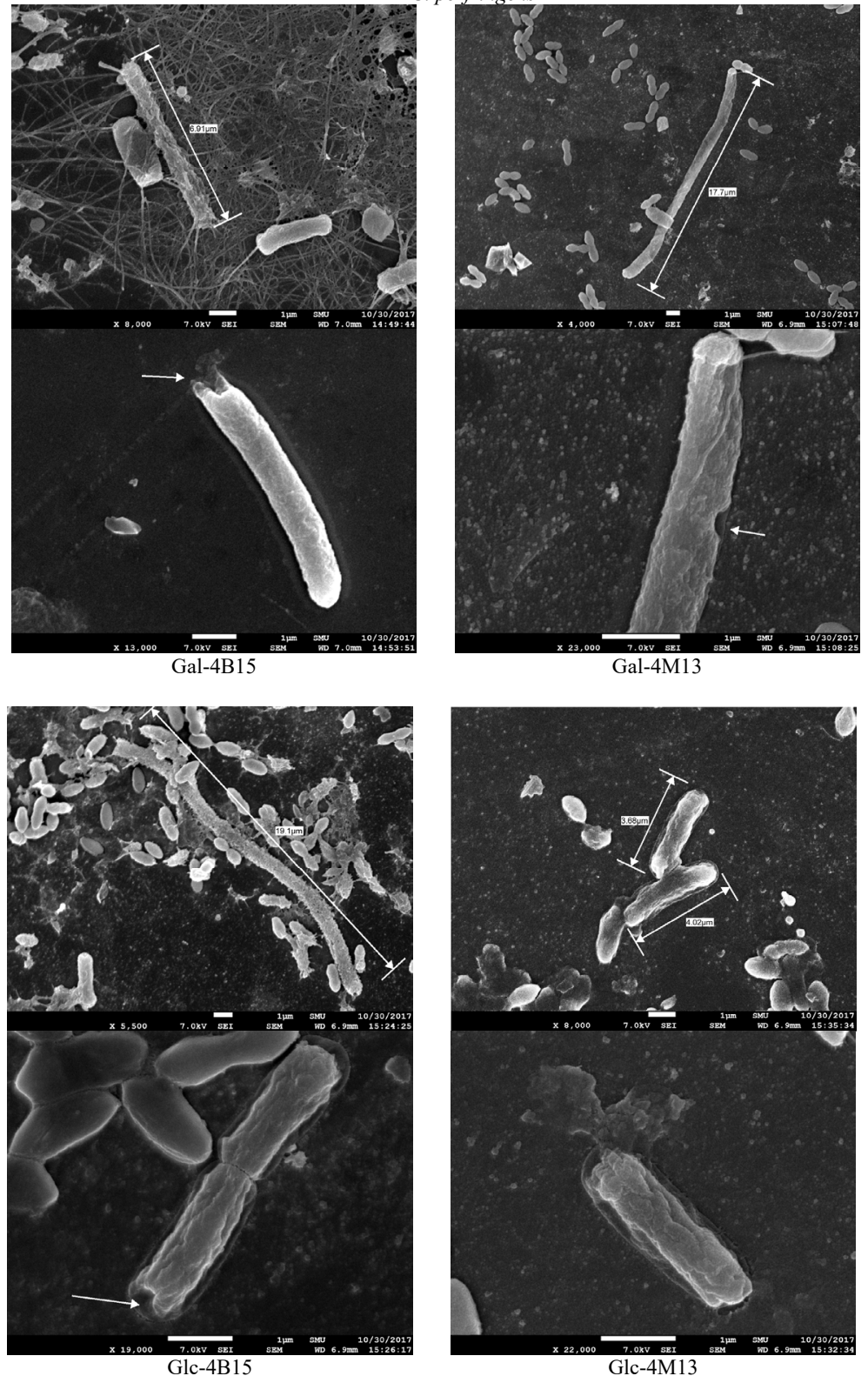

Figure 3. Morphological observation of Clostridium perfringens, which was exposed to fermented Maillard reaction products for $24 \mathrm{~h}$, using FE-SEM. Gal-4B15, Galactose + L. rhamnosus 4B15; Gal-4M13, Galactose + L. gasseri 4M14; Glc-4B15, Glucose + L. rhamnosus 4B15; Glc-4M13, Glucose + L. gasseri $4 \mathrm{M} 13$. 
brane damage, and it might be one of the modes to destroy C. perfringens cells. To date, physicochemical properties of dairy antimicrobial peptides, such as net charge, amphipathicity, hydrophobicity, etc., have shown effects on interaction with cell membranes and integration of the membranes with the peptides [21]. Therefore, it is assumed that peptides in FMRPs specifically interacted with the bacterial cell membranes and occurred the cell leakage.

\section{Morphological analysis}

The PI uptake assay showed that FMRP treatments caused cell membrane damages, which were confirmed visually by FE-SEM. FMRP-treated $C$. perfringens had an uneven cell membrane, and pores on the cell membrane surface (Figure 3). In addition, the lengths of the FMRP-treated bacteria increased from $2.0 \mu \mathrm{m}$ to $12.0 \mu \mathrm{m}$ in average and $19.1 \mu \mathrm{m}$ in maximum for $C$. perfringens. Normally each bacteria species consistently maintains their classical bacterial shapes with their complex mechanisms genetically and biochemically [22]. Bacterial cells were found to elongate in order to adjust stressful environments [23]. Everis and Betts [23] also suggested that the length of Clostridium spp. increases when they are exposed to stress. When the bacterial cell is exposed to high solute and nutrition concentration, the osmotic forces change the mechanical integrity of bacterial cell and determine the shape [24]. Thus, the elongation of the bacterial cells in this study would be a result of the stressful environment by FMRPs. Taken together with the result of iron chelation activity and PI uptake assay, FMRPs would have antimicrobial activity as they occurred cell membrane damages and iron chelating properties simultaneously.

\section{CONCLUSION}

The FMRPs (Gal-4B15, Gal-4M13, Glc-4B15, and Glc-4M13), which are already known for the functional properties, showed significant antimicrobial activity against $C$. perfringens. The antimicrobial activity of FMRPs would be caused by iron chelation and bacterial cell membrane damage. Moreover, FMRPs contributed to cause stress to $C$. perfringens as its elongation shows. Thus, the FMRPs can be used in various food to control the pathogen. In addition, it can be expected that consumption of FMRPs may control intestinal C. perfringens as health-promoting supplements.

\section{CONFLICT OF INTEREST}

We certify that there is no conflict of interest with any financial organization regarding the material discussed in the manuscript.

\section{ACKNOWLEDGMENTS}

This study was supported by Korea Institute of Planning and Evaluation for Technology in Food, Agriculture, Forestry and Fisheries (IPET) through High Value-added Food Technology Development Program, funded by Ministry of Agriculture, Food and Rural Affairs (MAFRA) (115006-03).

\section{REFERENCES}

1. Scallan E, Hoekstra RM, Angulo FJ, et al. Foodborne Illness Acquired in the United States-Major Pathogens. Emerg Infect Dis 2011;17:7-15. https://doi.org/10.3201/eid1701. p11101

2. Labbe RG, Juneja VK. Clostridium perfringens gastroenteritis. In: Morris JG, Potter ME, editors. Foodborne infections and intoxications. 4th ed. Waltham, MA, USA: Academic Press; 2013. p. 99-112.

3. Heo S, Kim MG, Kwon M, Lee HS, Kim GB. Inhibition of Clostridium perfringens using bacteriophages and bacteriocin producing strains. Food Sci Anim Resour 2018;38:88-98. https://doi.org/10.5851/kosfa.2018.38.1.88

4. Carman RJ, Sayeed S, Li J, et al. Clostridium perfringens toxin genotypes in the feces of healthy North Americans. Anaerobe 2008;14:102-8. https://doi.org/10.1016/j.anaerobe.2008.01. 003

5. Finegold SM, Summanen PH, Downes J, Corbett K, Komoriya T. Detection of Clostridium perfringens toxin genes in the gut microbiota of autistic children. Anaerobe 2017;45:1337. https://doi.org/10.1016/j.anaerobe.2017.02.008

6. Tremlett H, Bauer KC, Appel-Cresswell S, Finlay BB, Waubant E. The gut microbiome in human neurological disease: a review. Ann Neurol 2017;81:369-82. https://doi.org/10.1002/ ana. 24901

7. Freedman JC, Shrestha A, McClane BA. Clostridium perfringens enterotoxin: action, genetics, and translational applications. Toxins 2016;8:73. https://doi.org/10.3390/toxins8030073

8. Kim DH, Chun SH, Oh NS, Lee JY, Lee KW. Anti-inflammatory activities of Maillard reaction products from whey protein isolate fermented by Lactobacillus gasseri 4M13 in lipopolysaccharide-stimulated RAW264.7 cells. J Dairy Sci 2019;102: 7707-16.

9. Pyo MC, Yang SY, Chun SH, Oh NS, Lee KW. Protective effects of Maillard reaction products of whey protein concentrate against oxidative stress through an Nrf2-dependent pathway in HepG2 cells. Biol Pharm Bull 2016;39:1437-47. https://doi.org/10.1248/bpb.b16-00029

10. Oh NS, Kwon HS, Lee HA, et al. Preventive effect of fermented Maillard reaction products from milk proteins in cardiovascular health. J Dairy Sci 2014;97:3300-13. https://doi.org/10. 3168/jds.2013-7728

11.Oh NS, Lee JY, Lee HA, et al. Chemical characteristics and 
enhanced hepatoprotective activities of Maillard reaction products derived from milk protein-sugar system. J Dairy Sci 2016;99:947-58. https://doi.org/10.3168/jds.2015-10009

12.Rufián-Henares JA, Morales FJ. Functional properties of melanoidins: in vitro antioxidant, antimicrobial and antihypertensive activities. Food Res Int 2007;40:995-1002. https:// doi.org/10.1016/j.foodres.2007.05.002

13. Rufián-Henares JA, Morales FJ. Microtiter plate-based assay for screening antimicrobial activity of melanoidins against E. coli and S. aureus. Food Chem 2008;111:1069-74. https:// doi.org/10.1016/j.foodchem.2008.05.027

14. Rurián-Henares JA, Morales FJ. Antimicrobial activity of melanoidins against Escherichia coli is mediated by a membrane-damage mechanism. J Agric Food Chem 2008,56: 2357-62. https://doi.org/10.1021/jf073300+

15. Kim S, Lee H, Lee S, Yoon Y, Choi KH. Antimicrobial action of oleanolic acid on Listeria monocytogenes, Enterococcus faecium, and Enterococcus faecalis. PloS One 2015;10:e0118800. https://doi.org/10.1371/journal.pone.0118800

16. Kim S, Lee S, Lee H, et al. Evaluation on antimicrobial activity of psoraleae semen extract controlling the growth of grampositive bacteria. Food Sci Anim Resour 2017;37:502-10. https://doi.org/10.5851/kosfa.2017.37.4.502

17. Kim JS, Lee YS. Antioxidant activity of Maillard reaction products derived from aqueous glucose/glycine, diglycine, and triglycine model systems as a function of heating time.
Food Chem 2009;116:227-32. https://doi.org/10.1016/j. foodchem.2009.02.038

18. Parrow NL, Fleming RE, Minnick MF. Sequestration and scavenging of iron in infection. Infect Immun 2013;81:350314. https://doi.org/10.1128/IAI.00602-13

19. Frawley ER, Fang FC. The ins and outs of bacterial iron metabolism. Mol Microbiol 2014;93:609-16. https://doi.org/ 10.1111/mmi.12709

20. Crowley LC, Scott AP, Marfell BJ, Boughaba JA, Chojnowski G, Waterhouse NJ. Measuring cell death by propidium iodide uptake and flow cytometry. Cold Spring Harb Protoc 2016; 2016:pdb-prot087163. https://doi.org/10.1101/pdb.prot087163

21. Théolier J, Fliss I, Jean J, Hammami, R. Antimicrobial peptides of dairy proteins: from fundamental to applications. Food Rev Int 2014;30:134-54. https://doi.org/10.1080/87559129. 2014.896017

22. Justice SS, Hunstad DA, Cegelski L, Hultgren SJ. Morphological plasticity as a bacterial survival strategy. Nat Rev Microbiol 2008;6:162-8. https://doi.org/10.1038/nrmicro1820

23.Everis L, Betts G. pH stress can cause cell elongation in Bacillus and Clostridium species: a research note. Food Control 2001; 12:53-6. https://doi.org/10.1016/S0956-7135(00)00017-7

24. Misra G, Rojas ER, Gopinathan A, Huang KC. Mechanical consequences of cell-wall turnover in the elongation of a Gram-positive bacterium. Biophys J 2013;104:2342-52. https:// doi.org/10.1016/j.bpj.2013.04.047 